\title{
Do Intellectual Capital, Corporate Social Responsibility, and Good Corporate Governance Affect Indonesia's Mining Companies Value?
}

\author{
Nadia Azalia Putri ${ }^{1 *}$, Tatang Ary Gumanti ${ }^{2}$, Isti Fadah ${ }^{3}$ and Supriyadi ${ }^{4}$ \\ 1,2,3 University of Jember, Jalan Kalimantan 37, Jember,„Jawa Timur 68124 Indonesia \\ ${ }^{4}$ Jember State Polytechnic, Jalan Mastrip Sumbersari Jember, Jawa Timur 68124, Indonesia
}

\begin{abstract}
Objective -The purpose of this study was to analyze the effect of Intellectual Capital (IC), Corporate Social Responsibility (CSR) disclosure, and Good Corporate Governance (GCG) on the value of mining companies (as measured by Tobin's Q) listed in Indonesia Stock Exchange period 2011-2015.

Methodology/Technique - Intellectual capital was measured by Value Added Capital Employed (VACA), Value Added Human Capital (VAHU), and Structural Capital Value Added (STVA). CSR disclosure was measured using Global Reporting Initiative index. GCG was proxied using independent commissioner, managerial ownership, audit committee, and institutional ownership. Empirical analysis was conducted using linear multiple regression analysis. The samples consisted 15 mining firms.

Findings -The results showed that VACA, VAHU, and institutional ownership had a positive and significant effect on company value. STVA and independent commissioner have a positive but insignificant effect on company value. Audit committee and managerial ownership have a negative and insignificant effect on company value.

Novelty - The study suggests managers to improve the company value by investing IC subcomponents; that is, physical capital and human capital and also add the number of shares held by institutions.
\end{abstract}

Type of Paper: Empirical

Keywords: Company Value; Corporate Social Responsibility; Good Corporate Governance; Intellectual Capital. JEL Classification: M14, M41, M51.

\section{Introduction}

One of the main objectives of a company is to maximize its value. Company's value is the centre of corporate finance; however, calculating value of a company is not easy. First, different companies should be valued differently (for example, public company vs. private company). Second, the company's value depends on the aim of the valuation as well (one company can have several values, depending on the method). In the past, the company was evaluated through performance evaluation and firm tangible asset evaluation. Today, the type of assets named intangible assets is proposed to be used more for evaluating firms, generally these intangible assets are called intellectual capital (Pouraghajan, et al., 2013).

\footnotetext{
* Paper Info: Received: November 3, 2016

Accepted: April 13, 2017

* Corresponding author:

E-mail: azalianadia24@gmail.com

Affiliation: University of Jember, Indonesia.
} 
Intellectual capital (IC) has a strategic and crucial role within the company because one of the efforts in achieving the company's goal is to increase its intellectual capital (Chen et al., 2010). Klein and Prusak (1996:12) define intellectual capital as intellectual material that has been formalized, captured, and leveraged to produce a higher valued asset. Pulic (2000) propose a method to measure intellectual capital in a company using VAICTM (Value Added Intellectual Capital Coefficient). This method uses an indirect approach to measure intellectual capital by measuring the efficiency of value added as a result of the company's intellectual abilities. The main components of VAIC consist of the company's resources, i.e. physical capital (VACAvalue added capital employed), human capital (VAHU-value added human capital), and structural capital (STVA-structural capital value added).

In addition to the application of intellectual capital-based business for profit maximization, companies are required to keep paying attention to the role of stakeholders. That is why the company should be able to develop Corporate Social Responsibility (CSR) program. Corporate sustainability will only be assured if the company cares about the social and environmental dimensions as well. It is a fact how local community resistance, in different places and time, comes to companies that are considered not paying attention to social, economic and environmental life aspects (Adeneye et al., 2013).

The implementation of Good Corporate Governance (GCG) in a company is also required to maintain public trust. GCG can be assessed through institutional ownership (Tran, 2014), independent commissioner (Murni et al., 2016), audit committee (Cohen, 2014), and managerial ownership (Chen, 2013). Unfortunately, according to the survey conducted by McKinsey and Company and the Political and Economic Risk Consultancy (PERC) in 2000, Indonesia occupied the lowest position in the implementation of Good Corporate Governance in Southeast Asia (McKinsey, 2002). This indicates a very unfavorable position for Indonesia. According to PERC, poor corporate governance threatens the entry of foreign investors to Indonesia (Sutedi, 2011).

Many discussions have attempted to examine the effect of IC, CSR, and GCG on company value. A considerable number of studies (Chen et al., 2010; Berzkalne and Zelgalve 2013; Nuryaman, 2015) have discussed that intellectual capital positively affects firm value. If utilized optimally, the three intellectual resources of the self-employed i.e. capital, human capital and structural capital will create a superior Intellectual capital in the firm. Intellectual capital will facilitate the firm to excel in meeting the interests of all stakeholders, including investors. The investors in the capital market will show appreciation for the superiority of intellectual capital of the firm with a growing demand for stocks of these firms and will have an impact on the rise in the firm's value (Nuryaman, 2015).

Discussions about the effect of CSR on firm value have also been conducted by several researchers (Adeneye and Ahmed, 2015; Servaes and Tamayo, 2013; Gutsche et al., 2016). They proved that CSR disclosure is positively associated with firm value. World Business Council for Sustainable Development (WBCSD, 2004) defines CSR as the commitment of a business to contribute to sustainable economic development, working with employees, their families, the local community and society at large to improve their quality of life. The impacts of GCG have also been widely observed. Wallace and Zinkin (2005) define corporate governance as a set of provisions that enable the stockholders by exercising voting power to compel those in operational control of the firm to respect their interests. Garay and Maxilimiano (2008) proved that the number of board of directors positively affects firm value. Thanatawee (2014) and Tahir et al. (2015) state that institutional ownership positively affects firm value.

This research was conducted on mining companies listed in Indonesia Stock Exchange period 2011-2015. Mining companies in Indonesia have become one of strategic industries that play a significant role in national economic development. Based on data from the Indonesia Mining Association in 2014, Indonesia was the sixth biggest country that is rich in mineral resources, ranging from coal, oil and gas, gold, tin, etc. However, the uncertainty of global economic conditions has caused some strategic sectors of decrease in the national economy, one of which is mining sector. Based on the explanation, this study aims to analyze the effect of VACA, VAHU, STVA, CSR disclosure, independent commissioner, managerial ownership, audit committee, 
and institutional ownership on the value of mining companies listed in the Indonesia Stock Exchange period 2011-2015.

\section{Research Methodology}

The type of this research was hypothesis testing research. The test was based on research hypotheses proposed according to theoretical and empirical studies. In particular, this study was conducted to examine the effect of VACA, VAHU, STVA, CSR, institutional ownership, independent directors, audit committees, and managerial ownership on the value of mining companies listed in Indonesia Stock Exchange 2011-2015 period using multiple linear regression analysis. Data used in this study were quantitative data gathered from a company's financial statements of the years 2011-2015 including balance sheet, income statement, and statement of disclosure of Corporate Social Responsibility (CSR) and Good Corporate Governance (GCG). The data were gathered from the IDX official website (www.idx.co.id).The population in this study covered mining companies listed in Indonesia Stock Exchange during the 2011-2015 period. The sampling method was purposive sampling with the following criteria:

- All companies listed in Indonesia Stock Exchange and included in mining companies that published annual report from 2011 to 2015.

- The annual report contained complete data to calculate Tobin's Q, VACA, VAHU, STVA and showed the information of CSR disclosure, institutional ownership, independent commissioner, audit committee, and managerial ownership.

Multiple Regression Analysis was used to analyze the effect of VACA (X1), VAHU (X2), STVA (X3), CSR (X4), institutional ownership (X5), independent commissioner (X6), audit committee (X7), managerial ownership (X8) on the company's value (Y). Below table defines the variables used in this study.

Table 1. Operational Definition of Variable

\begin{tabular}{|l|l|}
\hline \multicolumn{1}{|c|}{ Variable } & \multicolumn{1}{c|}{ Definition } \\
\hline Tobin's Q (TQ) & $\begin{array}{l}\text { Measured as the market value of equity stocks plus the book value of debt, } \\
\text { divided by total assets }\end{array}$ \\
\hline $\begin{array}{l}\text { Value Added Capital Employed } \\
\text { (VACA) }\end{array}$ & Value added to create on capital sought by companies efficiently \\
\hline $\begin{array}{l}\text { Value Added Human Capital } \\
\text { (VAHU) }\end{array}$ & Value added generated by the funds spent on labor \\
\hline $\begin{array}{l}\text { Structural Capital Value Added } \\
\text { (STVA) }\end{array}$ & $\begin{array}{l}\text { Amount of capital structure needed to produce value added and an } \\
\text { indication of how successful structural capital in the process of value } \\
\text { creation in the company }\end{array}$ \\
\hline $\begin{array}{l}\text { Corporate Social Responsibility } \\
\text { (CSR) }\end{array}$ & $\begin{array}{l}\text { The disclosure of environmental aspect based on the Global Reporting } \\
\text { Index (GRI) containing 9 sub-indicator and 20 items of statement. }\end{array}$ \\
\hline Institutional Ownership (INSO) & $\begin{array}{l}\text { The cumulative percentage of company shareholding owned by the } \\
\text { institution such as insurance companies, banks, investment companies and } \\
\text { others }\end{array}$ \\
\hline Independent Commissioner (INCO) & $\begin{array}{l}\text { Member of the board of directors who are not affiliated with the moard of } \\
\text { directors divided by the total number of boards of directors }\end{array}$ \\
\hline Audit Committee (AUCO) & Number of audit committee in a company \\
\hline Managerial Ownership (MOWN) & The cumulative percentage of shares owned by managers \\
\hline
\end{tabular}




\section{Results}

\subsection{Descriptive Statistic}

Table 2. Descriptive Statistics of Variables $(\mathrm{N}=75)$

\begin{tabular}{|l|c|c|c|c|}
\hline \multicolumn{1}{|c|}{ Variable } & Minimum & Maximum & Mean & Std Deviation \\
\hline VACA & 0.0227 & 3.8645 & 0.550788 & 0.578 \\
\hline VAHU & -3.8586 & 11.6992 & 3.9419 & 3.2563 \\
\hline STVA & -0.4956 & 5.7939 & 0.8444 & 0.7647 \\
\hline CSR & 0.0333 & 0.7333 & 0.3278 & 0.1570 \\
\hline INCOM & 0.0000 & 0.5714 & 0.3088 & 0.1289 \\
\hline MOWN & 0.00001 & 0.7500 & 0.1961 & 0.2919 \\
\hline AUCO & 1.0000 & 4.000 & 3.01 & 0.5770 \\
\hline INSO & 0.0770 & 0.7951 & 0.4548 & 0.2173 \\
\hline TQ & 0.3266 & 7.9300 & 2.0588 & 1.8125 \\
\hline SOUrC:
\end{tabular}

Source: data was processed, 2016

According to the table 2, it can be seen the value of the minimum. maximum, average, and standard deviation for each variable both the dependent variable and independent variables, where:

- The value of VAHU is ranging from -3.85 to 11.69 and the mean is 3.77. It shows that 1 unit of human capital or labor cost can generate 3.77 units of a company's value added on average. The standard deviation of 3.23 shows that the range between the minimum and maximum is high. It indicates that the ability of human capital of each company to generate value added is various between firms.

- The highest value of STVA is 5.79 and the lowest one is -0.49 . The average value is 0.84 . It indicates that 1 unit of a company's value added can be generated from 0.84 unit of capital structure in average. The standard deviation of 0,76 shows that the range between the minimum and the maximum is relatively high. It indicates that the ability of the capital structure to generate value added is various enough.

- The average value of CSR is 0.32. It shows that mining companies disclose its CSR activity in the environmental aspect in the amount of $32 \%$ or about 10 items of 30 items of disclosure in average. The highest value is 0.73 and the lowest one is 0.03 . The standard deviation of 0.16 shows that the range between the minimum and the maximum is relatively low. It indicates that the company's disclosure of CSR, environmental activity does not vary.

- The highest value of INCOM or independent commissioner is 0.57 and the lowest one is 0 . The average value is 0.30 . It indicates that mining companies has $30 \%$ independent commissioner from the total of board of commissioner in average. The standard deviation of 0.12 shows that the range between the minimum and the maximum is relatively low. It indicates that the percentage of company's independent commissioner on its board of commissioner is not too various.

- The value of MOWN or managerial ownership is ranging from 0.0001 to 0.75 and the mean is 0,196 . It shows that on average the managers or the directors of mining companies own $19 \%$ of shares of whole outstanding shares. The standard deviation of 0.29 shows that the range between the minimum and the maximum is relatively low. It indicates that the percentage of mining company shares held by its managers are various enough.

- The highest value of AUCO or audit committee is 4.00 and the lowest one is 1.00 and the mean is 3.01. It shows that the mining company has 3 people on the audit committee on average. The standard deviation of 0.57 shows that the range between the minimum and the maximum is relatively high. It indicates that the number of audit committee in mining company is various enough.

- The value of INSO or institutional ownership is ranging from 0.07 to 0.8 and the mean is 0.454 . It shows that $45 \%$ of mining company shares are held by other institutions such as insurance company 
and bank. The standard deviation of 1.21 shows that the range between the minimum and the maximum is relatively high. It indicates that the mining company's value is various.

- The average value of TQ or Tobin's Q is 2.05. It shows that the market value of mining companies is twice greater than its book value. Tobin's Q value that is greater than 1 shows the good corporate growth. The highest value is 7.9 and the lowest one is 0.32 . The standard deviation of 0.247 shows that the range between the minimum and the maximum is relatively low.

\subsection{Multiple Linear Regression Analysis}

The population of the study covered 44 mining companies. The purposive sampling criteria generated 15 firms being eligible as the sample. The sample size was $34 \%$ of the population. The data have already normally been distributed and the model has passed classical assumption tests (normality, multicollinearity, heteroscedasticity, and autocorrelation test). The hypotheses are all of independent variables which have a positive and significant effect on company value partially. The results of multiple regression analysis can be seen in Table 3. The sign value of standardized coefficients of VACA, VAHU, STVA, CSR, INCOM, and INSO were consistent with the prediction before. Those six variables showed a positive direction. Otherwise, MOWN and AUCO showed a negative direction which was not consistent with the prediction. However, only VACA, VAHU, and INSO that significantly affected TQ. STVA, CSR, INCOM, MOWN, and AUCO has insignificant effect on the company's value. Thus, the variables that have consistent significance and direction are only VACA, VAHU, and INSO.

Table 3. Result of Multiple Regression Analysis

\begin{tabular}{|l|c|c|c|c|c|c|}
\hline \multicolumn{1}{|c|}{ Model } & $\begin{array}{c}\text { Expecte } \\
\text { d Sign }\end{array}$ & $\begin{array}{c}\text { Standardized } \\
\text { Coefficient }\end{array}$ & $\begin{array}{c}\text { t- } \\
\text { value }\end{array}$ & Sig. & Description & Decision \\
\hline Constant & & 1.426 & 1.047 & 0.299 & & \\
\hline VACA & + & 0.241 & 2.113 & $0.032 *$ & Significant & $\mathrm{H}_{01}$ is rejected \\
\hline VAHU & + & 0.319 & 2.504 & $0.012 *$ & Significant & $\mathrm{H}_{02}$ is rejected \\
\hline STVA & + & 0.083 & 0.757 & 0.951 & Not significant & $\mathrm{H}_{03}$ is accepted \\
\hline CSR & + & 0.053 & 0.413 & 0.618 & Not significant & $\mathrm{H}_{04}$ is accepted \\
\hline INCOM & + & 0.002 & 0.014 & 0.136 & Not significant & $\mathrm{H}_{05}$ is accepted \\
\hline MOWN & + & -0.037 & - & 0.664 & Not significant & $\mathrm{H}_{06}$ is accepted \\
\hline AUCO & + & -0.205 & - & 0.632 & Not significant & $\mathrm{H}_{07}$ is accepted \\
\hline INSO & + & 0.301 & 2.359 & $0.028 *$ & Significant & $\mathrm{H}_{08}$ is rejected \\
\hline
\end{tabular}

Source: data was processed, 2016

Therefore, the regression model is generated as follows:

$$
\begin{aligned}
\mathrm{Y} & =1.426+0.241 \mathrm{VACA}+0.319 \mathrm{VAHU}+0.083 \mathrm{STVA}+0.053 \mathrm{CSR} \\
& +0.002 \mathrm{INCOM}-0.037 \mathrm{MOWN}-0.2015 \mathrm{AUCO}+0.301 \mathrm{INSO}+\varepsilon
\end{aligned}
$$

\section{Discussion}

\subsection{The Effect of Intellectual Capital on Company's Value}

This study found that VACA and VAHU positively and significantly affect the value of mining companies. This finding is consistent with Chen et al. (2010) who state that VACA and VAHU give a positive impact on the company's value. The mining company is one of companies that rely heavily on its physical capital or equity because it needs a lot of heavy equipment and machines to support its activities. It also needs excellent human capital in the form of knowledge, technological mastery, innovativeness, work related knowledge and 
competencies, etc. Mining companies should efficiently utilize the physical and human capitals as they are an important aspect to run the company business. Through a good management of available physical and human capitals, companies can increase the value-added that eventually can work the company's value up. Meanwhile, STVA positively and insignificantly affects the value of mining companies. Although Chen (2010) states that structural capital significantly influences market value, he argues that STVA is not an appropriate measure because it only reflects the proportion of the value-added from structural capital, which is only measured by the VA reduced by human capital.

\subsection{The Effect of Corporate Social Responsibility (CSR) Disclosure on Company's value}

This study found that CSR has a positive and insignificant effect on the company's value. This is due to several phenomena: investors still do not realize how important CSR when buying stocks, CSR disclosure by the company is poor, and CSR variable cannot be measured directly. According to Indonesian State-Owned Enterprises Ministry Portal (2012), there are three reasons why Indonesian people buy stocks: (1) receiving capital gain or increase in stock price, (2) receiving dividend payments, and (3) getting voting rights and trying to take part in the company's management. Generally, investors in Indonesia tend to buy stocks for receiving capital gain or daily trading regardless the sustainability of the company in the long-term, whereas CSR is one of the company's long-term strategies to keep its sustainability, and its effect cannot be perceived in shortterm. This finding is conformable to Dagiliene (2013) who proved that CSR disclosure has no effect on the company's value. Contrarily, Adeneye and Ahmed (2015) established that listed firms have better increased in financial performance as they are more corporate socially responsible. The ability of a company to engage in environmental protection, charitable programmes and community relations has made them to exhibit sound and increased their performance.

\subsection{The Effect of Good Corporate Governance on Company's value}

The statistical results showed that only institutional ownership that positively and significantly affects firm value. This finding supports the research conducted by Tahir et al. (2015) confirming that institutional shareholder having own majority of company shares has bigger rights over company's control. With that control, institutional ownership is able to affect the company's financial decision, so it can still uphold the main goal of the company i.e. increasing the value and the welfare of shareholders. Related with monitoring function, institutional investor has better ability to monitor management's action than individual investors. Institutional ownership will not easily be misled by manipulation done by a manager, so it can increase the company's performance and value. The larger the institutional ownership, the more efficient the utilization of assets will be and it can prevent wasting and profit manipulation by the manager. However, the results revealed that independent commissioner has no significant effect on firm value and two other variables; audit committee and managerial ownership have a negative and insignificant effect on mining company value.

\section{Conclusion}

The objective of this study was to examine the effect of IC, CSR, and GCG on the value of Indonesia mining companies during 2011-2015. First of all, the empirical results showed that Value Added Capital Employed (VACA) and Value Added Human Capital (VAHU), and institutional ownership have a positive and significant impact on company value. This result entailed that when organizations have a higher level of investment in the physical capital and human capital, the company value will advance. This result supports the result from Chen et al. (2010) and Berzkalne and Zelgalve (2013). The same matter goes to institutional ownership. When institutional shareholder that owns majority of company shares has bigger rights over company's control, the company value will increase. This finding is in line with the study conducted by Thanatawee (2014) and Tahir et al. (2015). As a result, efforts taken to enhance the effectiveness of VACA, 
VAHU, and institutional ownership will be useful in enhancing future company value. The empirical findings provide important managerial implication. Managers can strive to improve the company value by investing IC subcomponents; that is, physical capital and human capital. Managers can also enhance the company value by adding the number of shares held by institutions. These kinds of effort can be attempted to foster the performance of mining companies in Indonesia as one of strategic companies in this country.

\section{References}

Adeneye, B. \& Ahmed, M. (2015). Corporate Social Responsibility and Company Performance. Journal of Business Studies Quarterly, 7(1), 1-13.

Berzkalne, I., \& Zelgalve, E. (2014). Intellectual capital and company value. Procedia-Social and Behavioral Sciences, 110, 887-896.

Chen, M. (2013). Adjustments in Managerial Ownership and Changes in Firm Value. International Review of Economics and Finance, 25, 1-12

Chen, M., Cheng, S., \& Hwang, Y. (2010). An Empirical Investigation of the Relationship between Intellectual Capital and Firms' Market Value and Financial Performance. Journal of Intellectual Capital, 6, 159 - 176.

Cohen, J. (2014). The Effect of Audit Committee Industry Expertise on Monitoring the Financial Reporting Process. The Accounting Review, 89(1), 243-273

Dagiliene, L. (2013). The Influence of Corporate Social Reporting to Company's Value in a Developing Economy. Procedia Economics and Finance, 5, 212-221.

Garay, U. \& Maximiliano G. (2008). Corporate Governance and Firm Value: The Case of Venezuela". Corporate Governance International Review, 16, 194-209.

Gutsche, R., Schulz, JF., \& Gratwohl, M. (2016). Firm-value effects of CSR disclosure and CSR performance. Retrieved from https://papers.ssrn.com/sol3/papers.cfm?abstract_id=2821691

Klein, D.A \& Prusak, L. (1994), Characterising Intellectual Capital. Cambridge: Ernst and Young.

McKinsey. (2002). McKinsey Global Investor Opinion Survey on Corporate Governance- Key findings, Retrieved from http://www.mckinsey.com/

Murni, Y.,Sudarmaji, E., \& Sugihyanti, E. (2016). The Role of Institutional Ownership, Board of Independent Commissioner and Leverage: Corporate Tax Avoidance in Indonesia. IOSR Journal of Business and Management, $18,79-85$

Nuryaman. (2015). The Influence of Intellectual Capital on The Firm's Value with The Financial Performance as Intervening Variable. Procedia - Social and Behavioral Sciences, 211, 292 - 298

Pouraghajan, A., Ramezani,A. \& Mohammadzeh, S. (2013).Impact of Intellectual Capital on Market Value and Firms' Financial Performance, World of Sciences Journal, 12, 197-208.

Pulic. (2000). MVA and VAIC Analysis of Randomly Selected Companies from Ftse 250.Retrieved from www.vaicon.net/start.htm

Servaes, H. \& Tamayo, A. (2013). The Impact of Corporate Social Responsibility on Firm Value: The Role of Customer Awareness. Management Science, 59, 1045-1061

Sutedi, Adrian. (2011), Good Corporate Governance. Jakarta: Sinar Grafika.

Tahir, S.H., Saleem, M., \& Arshad, H. (2015). Institutional Ownership And Corporate Value: Evidence From Karachi Stock Exchange (Kse) 30-Index Pakistan. Praktični Menadžment, 6, 41-49.

Thanatawee, Y. (2014). Institutional Ownership and Firm Value in Thailand. Asian Journal of Business and Accounting, 7, 1-22.

Tran, D. (2014). Multiple Corporate Governance Attributes and The Cost of Capital- Evidence from Germany. The British Accounting Review, 30, 1-19

Wallace, P. \& Zinkin, J. (2006). Mastering Business in Asia: Corporate Governance. Singapore: Wiley India.

World Business Council for Sustainable Development (WBCSD). (2004). Cross-cutting themes-Corporate responsibility. Retrieved from http://www.wbcsd.org/ 